\title{
ADDITIONS TO THE EPACRIDACEAE IN TASMANIA
}

\author{
by S.J. Jarman and C.M. Mihaich \\ (with three text-figures)
}

Three new taxa are described from the Epacridaceae, including a new species from each of Cyathodes and Epacris, and a subspecies from Monoteca. All are endernic to Tasmania.

Key Words: Tasmania, Epacridaceae, Cyathodes, Epacris, Monotoca.

In BANKS, M.R. et al. (Eds), 1991 (31:iii): ASPECTS OF TASMANIAN BOTANY - A TRIBUTE TO WINIFRED CURTIS. Roy. S•c. Tasm. Hobart: 99-103 https://doi.org/10.26749/rstpp.124.2.99

\section{INTRODUCTION}

The Epacridaceae is one of the most widespread and diverse plant families in Tasmania. Seventy-five species are recognised in Curtis (1963), the most comprehensive taxonomic treatment available for Tasmanian members of the group. Subsequent work on the family (Gray 1971, Willis 1972, Jarman 1974, 1975, 1988, Jarman \& Crowden 1977, 1978, Menadue \& Crowden 1983, Crowden 1986, Mihaich 1989) has increased the number of species recognised in Tasmania to 82 (see Buchanan et al. 1989) with new records or additional taxa being documented in Acrotriche, Cyathodes, Epacris, Monotoca and Richea. In this present paper, new species from Cyathodes and Epacris are described, along with a new subspecies of Monotoca linifolia.

\section{TAXONOMY}

\section{Cyathodes sulcata C.M. Mihaich, sp.nov.}

Frutex humilis compactus, ad $0.4 \mathrm{~m}$ altus, ramis ascendentibus, caules juvenes puberuli, vetustiores glabri.Penulae persistentes per annosplures. Folia versus extramitates ramonum in fasciculis annuis aggregata vel in ramis vetustioribus absentia vel sparsa, suberecta vel interdum patentia; lamina oblonga-ovata, $8-11 \mathrm{~mm}$ longa, 2-3 mm lata, supra viridis, plus minusve nitida, sulcis 1(-3) longitudinalibus, basi puberula, subtus glauca, pilis brevibus erectis, nervis 3-5 inramosis; apex apiculatus vel in foliis vetissimis obtusus scariosusque; margo leviter recurvus, glaber vel versus apicem interdum ciliatus; petiolus $1.5-2.5 \mathrm{~mm}$ longus, supra puberulus. Plantae gynodioeciae. Flores axillares, solitarii vel interdum duo, unusquisque bractea una et bracteolis duabus; bracteae, bracteolae et sepala ovata vel late ovata, obtusa, glabra, marginibus ciliatis, bractae $0.7-0.8 \mathrm{~mm}$ longae, $0.6-1 \mathrm{~mm}$ latae, bracteolae
1.6-2 mm longae, $1.7-2 \mathrm{~mm}$ latae, sepala $2.4-3.2 \mathrm{~mm}$ longa, 1.6-2.2 mm lata. Corolla eburnea, crassa, cylindrica; tubus $2.5-2.7 \mathrm{~mm}$ longus ( ), 2.7-4.2 mm longus ( ), intra pubescens; lobi triangulares, erecti vel patentes, $1.5-2.1 \mathrm{~mm}$ longi, intra ad infernum $2 / 3$ vel $1 / 2$ dense barbati et versus apicem prominenter incrassati atque glabri; apex saepe incurvus. Antherae inclusae, 1-1.3 mm longae ( ), $0.6 \mathrm{~mm}$ longae ( ), supra medium affixa. Ovarium 0.7-0.9 mm altum, 1.2-1.4 mm latum, 5-8 loculare, glabrum; nectarium leviter lobatum, $0.5 \mathrm{~mm}$ altum; stylus glaber, $0.9-1.4 \mathrm{~mm}$ longus; stigma parvum. Fructus depressus, 2-3 mm altus, 5-7 mm latus, nubus laevis nitidus.

\section{Typus}

Tasmania: Mt Read, 1050 m a.s.l., C.M. Mihaich, 8.xi.1988. Holotypus: HO 122595. Isotypus: NSW.

\section{Description}

Low compact shrub, up to $0.4 \mathrm{~m}$ high, with ascending branches; young stems puberulent, older stems glabrous. Scales of leaf-buds persisting for several years. Leaves crowded towards the ends of the branches in annual clusters but absent or scattered on older branches, suberect to spreading; lamina oblong-ovate, 8-11 mm long, 2-3 mm broad, apex apiculate, or blunt and scarious in oldest leaves; margins slightly recurved, glabrous or occasionally ciliolate towards the tip; upper surface of mid-season's leaves with $1(-3)$ longitudinal grooves, green, more or less shiny, puberulent at the base; lower surface with 3-5 unbranched veins, glaucous, covered by short erect hairs; petiole $1.5-2.5 \mathrm{~mm}$ long, upper surface puberulent. Plants gynodioecious. Flowers axillary, \pm sessile, solitary with a rudimentary bud or occasionally two together, clustered near the ends of the branches, each flower subtended by one bract and two bracteoles; bracts, bracteoles and sepals ovate to broadly ovate, obtuse, glabrous, with ciliate margins, bracts $0.7-0.8 \mathrm{~mm}$ long, $0.6--1 \mathrm{~mm}$ broad, bracteoles 
1.6-2 $\mathrm{mm}$ long, $1.7-2 \mathrm{~mm}$ broad, sepals $2.4-3.2 \mathrm{~mm}$ long, $1.6-2.2 \mathrm{~mm}$ broad. Corolla cream, thick, cylindrical; tube $2.5-2.7 \mathrm{~mm}$ long (female), $2.7-4.2 \mathrm{~mm}$ long (hermaphrodite), pubescent on the inner surface; lobes triangular, erect to spreading, $1.5-2.1 \mathrm{~mm}$ long, densely bearded inside on the lower $2 / 3-1 / 2$, hairs deflexed, glabrous and prominently thickened towards the apex; tip often incurved. Anthers enclosed, 1-1.3 mm long (hermaphrodite), $0.6 \mathrm{~mm}$ long (female), attached above the middle. Ovary $0.7-0.9 \mathrm{~mm}$ high, $1.2-1.4 \mathrm{~mm}$ wide, 5-8 celled, glabrous; nectary slightly lobed, $0.5 \mathrm{~mm}$ high; style glabrous, 0.9-1.4 mm long; stigma small. Fruit a depressed sphere, $2-3 \mathrm{~mm}$ high, $5-7 \mathrm{~mm}$ wide, red, smooth and shiny.

\section{Distribution and Habitat}

Cyathodes sulcata is endemic to Tasmania where it occurs in subalpine scrub and heathland. It is restricted to the western mountains above about $950 \mathrm{~m}$.
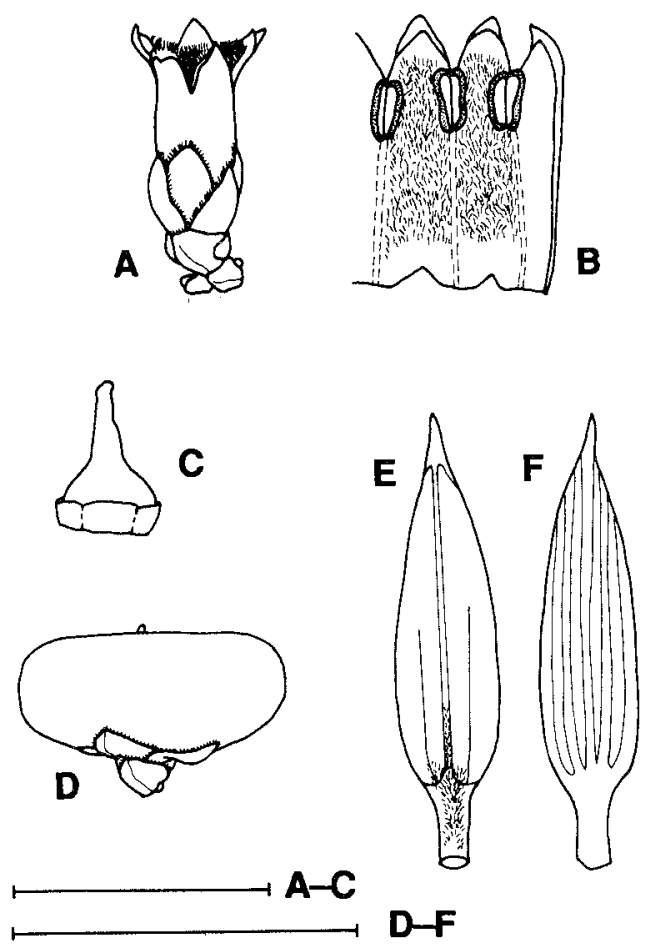

FIG. 1 - Cyathodes sulcata: (A) flower, (B) inner surface of the corolla, (C) gynoecium, (D) fruit, (E) leaves of mid-season's growth (upper surface), (F) leaves of mid-season's growth (lower surface). (Scale bars $=5 \mathrm{~mm}$.)

\section{Specimens Examined}

Tasmania ( all at $\mathrm{HO}$ unless otherwise stated): between Barron Pass and Artichoke Valley (HO 4155); C. Elliott (HO 4149); J. de Bavay (HO 92863); L. Rodway 493; A. Moscal (HO 78057); S.J. Jarman (HO 26699); M.J. Brown 14; A.M. Buchanan 884; A. Moscal 9379; R.K. Crowden 8511-08, 8602-04 (herb. CROWDEN); S.J. Jarman 291; I. Olsen 76 (NSW). [Further details of specimens listed in this paper, e.g. collecting site and date, are available from the Herbaria noted or from the Royal Society of Tasmania Library (Archives), GPO Box 1166M, Hobart, Tasmania, Australia 7001. Ed.]

\section{Comments}

Cyathodes sulcata (fig. 1) is closely allied to $C$. petiolaris, appearing similar in growth and habitat conditions but differing in features of the leaf, corolla and fruit. For example, the leaf is usually somewhat longer in $C$. sulcata (8-11 $\mathrm{mm}$ compared with 6-9 $\mathrm{mm}$ in $C$. petiolaris) with a recurved margin, and the distinct midrib groove on the upper surface of midseason C. sulcata leaves is absent from similar leaves of $C$. petiolaris. The corolla is cylindrical in C. sulcata while in $C$. petiolaris it is constricted at the throat and bulbous below. Distribution of hairs on the corolla lobes is restricted to the lower parts in C. sulcata where they are deflexed towards the tube, are of similar length and appear ranked. In C. petiolaris, the upper half of the lobes is covered with long, dense, tangled hairs and the lower half by short hairs. Other differences include a glabrous ovary and shiny red fruit surface in C. sulcata compared with a densely puberulent ovary and dull, often red-black fruit in C. petiolaris. The two species also have disjunct distributions. C. sulcata is recorded from the southwestern and western mountains of Tasmania, while $C$. petiolaris is restricted to the mountains of the Central Plateau and southeast.

The specific epithet of $C$. sulcata is derived from the Latin adjective, sulcatus, and refers to the grooves of the upper leaf surface.

\section{Epacris glabella S.J. Jarman, sp.nov.}

Frutex ad 1--2 m altus caulibus erectis gracilibus; ramuli glabri vel pilis brevibus sparsis paucis. Folia erectopatentia; lamina obovata vel late elliptica vel ovata, 3.5-7 mm longa, 2-3.5 mm lata, plana vel leviter concava, crassa, nitida, supra glabra vel basi pilis brevibus paucis, subtus glabra, distaliter leviter carinata; apex obtusus vel acutus, breviter incurvus; margo integer vel versus apicem scabridus; petiolus $0.6-1.2 \mathrm{~mm}$ longus, supra glaber vel puberulus, subtus glaber. Flores solitarii, axillares; pedicelli $2-3 \mathrm{~mm}$ longi. Bracteae 
10-20, ovatae, $0.6-3 \mathrm{~mm}$ longae, $0.6-2 \mathrm{~mm}$ latae, ciliolatae; sepala ovata-elliptica, $3-4 \mathrm{~mm}$ longa, $1.6-2 \mathrm{~mm}$ lata, ciliolata. Corolla alba; tubus infundibuliformis, $2.5-3.5 \mathrm{~mm}$ longus; lobi 3-5 mm longi, 3-3.5 mm lati, ovati apicibus obtusis. Stamina exserta; antherae $1.2-1.7 \mathrm{~mm}$ longae, $0.5-0.6 \mathrm{~mm}$ latae, filamenta 1.5-2 mm longa. Nectarium e squamis 5 obtusis latis constatum; squamae $0.25-3 \mathrm{~mm}$ longae. Ovarium $1.2-1.4 \mathrm{~mm}$ diametro; stylus $2.5-4.5 \mathrm{~mm}$ longus.

\section{Typus}

Tasmania: Serpentine Hill on a rocky hillside in heathland and scrub, $340 \mathrm{~m}$ a.s.l., S.J. Jarman \& G. Kantvilas, 27.ix.1986. Holotypus: HO 120611. Isotypi: MELB, CANB, NSW.

\section{Description}

Shrub 1-2 m tall, with erect slender branches; branchlets glabrous or with a few short scattered hairs. Leaves half spreading; lamina obovate to broadly elliptical to ovate, $3.5-7 \mathrm{~mm}$ long, $2-3.5 \mathrm{~mm}$ wide, flat or slightly concave, thick, shiny, upper surface glabrous or with a few short hairs at the base, lower surface glabrous, slightly keeled in the upper part, apex acute or obtuse with a very short incurved tip, margin entire or rough towards the apex with a few very small hyaline teeth; petiole $0.6-1.2 \mathrm{~mm}$ long, glabrous, or puberulent on the upper surface. Flowers solitary, axillary; pedicels $2-3 \mathrm{~mm}$ long. Bracts 10-20, 0.6-3 mm long, $0.6-2 \mathrm{~mm}$ wide, ovate, ciliolate, apex acute; sepals narrowly ovate to elliptical, $3-4 \mathrm{~mm}$ long, 1.6-2 mm wide, ciliolate, apex acute. Corolla white; tube funnel-shaped, $2.5-3.5 \mathrm{~mm}$ long, lobes ovate with an obtuse apex, 3-5 mm long, 3-3.5 mm wide. Stamens exserted; anthers $1.2-1.7 \mathrm{~mm}$ long, $0.5-0.6 \mathrm{~mm}$ wide, filaments $1.5-2 \mathrm{~mm}$ long. Nectary of 5 broad blunt scales, scales $0.25-0.3 \mathrm{~mm}$ long. Ovary $1.2-1.4 \mathrm{~mm}$ in diameter, style $2.5-4.5 \mathrm{~mm}$ long.

\section{Distribution}

Epacris glabella is endemic to Tasmania and has been recorded from two locations on the West Coast where it grows on serpentine soils. It occurs in Eucalyptus nitida dry sclerophyll woodland near the Heazlewood River (Davies 1988) and in heathland/scrub vegetation at Serpentine Hill near Renison Bell.

\section{Specimens Examined}

Tasmania (all at HO): S.J. Jarman \& R.K. Crowden (HO 120619), S.J. Jarman \& G. Kantvilas (HO 120617), M.J. Brown (HO 120616), J. Davies (HO 120615).

\section{Comments}

Epacris glabella (fig. 2) has close affinities with $E$. tasmanica, $E$. virgata and $E$. exserta, sharing with these species floral characters such as exserted anthers, funnel-shaped corolla tube and a comparatively long style which reaches to the anthers or beyond. It differs from each of these species in leaf shape, in the essentially glabrous branchlets and in its occurrence on, and restriction to serpentine soils.

The specific epithet is derived from the Latin adjective, glaber, and relates to the branchlets which are glabrous or nearly so.

\section{Monotoca linifolia (Rodw.) W.M. Curtis}

\section{Description}

Small to medium shrub, $0.3-2 \mathrm{~m}$ high; branchlets ridged, with short stiff hairs. Leaves narrow-oblong to oblong to elliptical, 4-20 mm long, $1.5-3 \mathrm{~mm}$ wide, glabrous, margin recurved or revolute, upper surface green, lower surface paler or glaucous with 3-5 branched or unbranched veins, apex acute to broadly acute or obtuse with a short sharp point, $0.2-0.6 \mathrm{~mm}$ long, or obtuse with a small callous tip; petiole $0.5-1.25 \mathrm{~mm}$ long, often red. Plants gynodioecious. Inflorescence axillary; flowers $(1-) 2-6(-8)$ in a short spike which is usually nodding, rarely in a raceme, the uppermost flower with a rudimentary bud at the base; peduncle with short stiff hairs. Flowers subtended by a bract and two bracteoles; bracteoles broadly ovate, $0.5-1 \mathrm{~mm}$ long, $0.6-1 \mathrm{~mm}$ wide, ciliolate, apex obtuse to bluntly acute; sepals
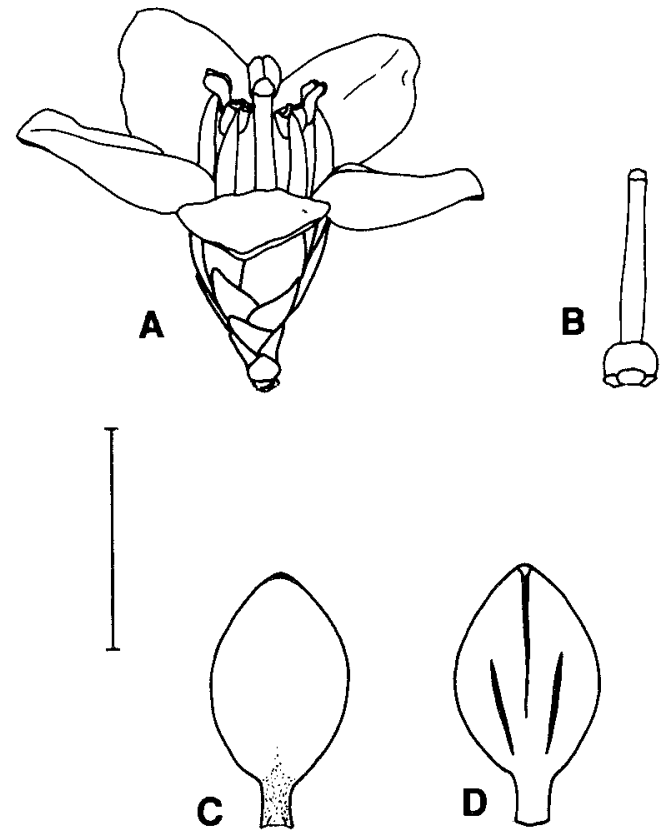

FIG. 2 - Epacris glabella: (A) flower, (B) gynoecium, (C) leaf (upper surface), (D) leaf (lower surface). (Scale bar $=5 \mathrm{~mm}$.) 
ovate to el liptical, $0.8-1.25 \mathrm{~mm}$ long, $0.6-1 \mathrm{~mm}$ wide, ciliolate, apex obtuse. Petals 4 or 5, white or sometimes tinged with pink. Hermaphrodite flowers with lobes $0.8-1.1 \mathrm{~mm}$ long, $0.8-1 \mathrm{~mm}$ wide, tube $0.7-1 \mathrm{~mm}$ long; anthers exserted, $0.4-0.6 \mathrm{~mm}$ long, $0.25-0.35 \mathrm{~mm}$ wide, filaments $0.4-0.6 \mathrm{~mm}$ long. Female flowers with lobes $0.6-1 \mathrm{~mm}$ long, $0.6-0.8 \mathrm{~mm}$ wide, tube 0.5 $0.8 \mathrm{~mm}$ long; anthers $0.15-0.25 \mathrm{~mm}$ long, $0.1-0.15 \mathrm{~mm}$ wide, filaments $0.2-0.4 \mathrm{~mm}$ long. Nectary of oblong or rounded scales, rarely with an acute apex; scales $0.2-0.4 \mathrm{~mm}$ wide, $0.25-0.5 \mathrm{~mm}$ high. Ovary with $1-4$ locules, $0.3-0.7 \mathrm{~mm}$ in diameter, style $0.2-0.5 \mathrm{~mm}$ long. Drupe spherical or ovoid, white, pink or purple, 2-4 $\mathrm{mm}$ in diameter.

\section{Monotoca linifolia (Rodw.) W.M. Curtis ssp. linifolia}

\section{Typus}

Tasmania, Huon Road, L. Rodway, ii.1893. Holotypus: HO 5997.

\section{Description}

Shrub 1-2 m tall, leaves (6-)8-20 mm long, apex mostly acute to broadly acute, mucronate. Flowers with 4 petals, ovary with $1(-2)$ locule(s).

\section{Distribution}

Southern and southeastern Tasmania including the Wellington Range, Snug Tiers, Longley, Margate and the Huon River area.

\section{Specimens Examined}

Tasmania (all at HO): W.M. Curtis (HO 5451, 107110, 5448); D.A. Ratkowsky (HO 107117, 107115, 107114); S.J. Jarman \& R.K. Crowden (HO120631); M. Allan (HO 78084); D.A. \& A.V. Ratkowsky (HO 107116); A.M. Gray 243; S.J. Jarman 17; A. Moscal 787, 756, 998, 987; S. Blackhall (HO 82584); M.J. Brown (HO 120622).

\section{Monotoca linifolia (Rodw.) W.M. Curtis ssp. algida S.J. Jarman, ssp. nov.}

A Monotoca linifolia ssp. linifolia floribus pentameris, frutice breviore et foliis plus brevioribus differt.

\section{Typus}

Tasmania: Mt Rufus, Canal Road, $780 \mathrm{~m}$ a.s.l., S.J. Jarman \& G. Kantvilas, 28.ix.1986. Holotypus: HO 120620. Isotypi: AD, MEL, CANB, NSW, PERTH.

\section{Description}

Small shrub, 0.3-1 $\mathrm{m}$ high; leaves 4-8(-10) mm long, apex broadly acute to obtuse, mucronate or sometimes with a callous tip. Petals 5, ovary with $(1-) 2-3(-4)$ locules.

\section{Distribution}

Widespread in western and central parts of the Central Plateau, and at medium to high altitudes in western and southwestern Tasmania. It occurs in subalpine eucalypt forest, at the margins of rainforest and in subalpine heathlands and scrub.

\section{Specimens Examined}

Tasmania (all at HO): H.F. Comber 2205; C. Elliott (HO 5467); W.M. Curtis (HO 5465, 5463, 107099); W.M. Curtis \& Talbot de Malahide (HO 106287); S.J. Jarman \& R.K. Crowden (HO 120629); M. Allan (HO 26413); A.M. Gray 282; J.R. Busby 136; J.M. Powell 1576; A. Moscal 1059, 1602, 1728, 1855, 1970, 2040 , 1574; P. Collier 1312; S.J. Jarman (HO 120630, 120627 , 120626, 120628); S.J. Jarman \& G. Kantvilas (HO $120625,120624,120623,120621$ ); P. Collier (HO 79086).

\section{Comments}

The two subspecies (fig. 3) differ in the number of floral parts, with $M$. linifolia ssp. algida having five petals, sepals and stamens whilst $M$. linifolia ssp. linifolia has only four. In addition, the latter is mostly unilocular whereas $M$. linifolia ssp. algida usually has two or three locules in the ovary. M. linifolia ssp. algida characteristically forms a smaller, more robust plant than M. linifolia ssp. linifolia, with shorter, stiffer leaves, and in some populations the apex of the leaves has a short callous point, a condition not known to occur in M. linifolia ssp. linifolia.

Although the two subspecies are distinct across much of their range, some populations show intergrading forms or mixtures of the characteristics which normally separate the two. For example, populations occur along the Gordon Road and in the Florentine Valley in which individual plants have flowers with both four and five petals, softer leaves and more open foliage resembling $M$. linifolia ssp. linifolia and a multilocular ovary like that found in $M$. linifolia ssp. algida. Specimens from Moonlight Ridge also occupy an intermediate position since they have four-petalled flowers but two or three locules in the ovary, and short leaves.

The epithet algida is derived from the Latin adjective, algidus, meaning "cold" and alludes to the occurrence of the subspecies in areas (central, western and southwestern Tasmania) which are generally colder than those in which $M$. linifolia ssp. linifolia is found (southeastern and southern Tasmania). 

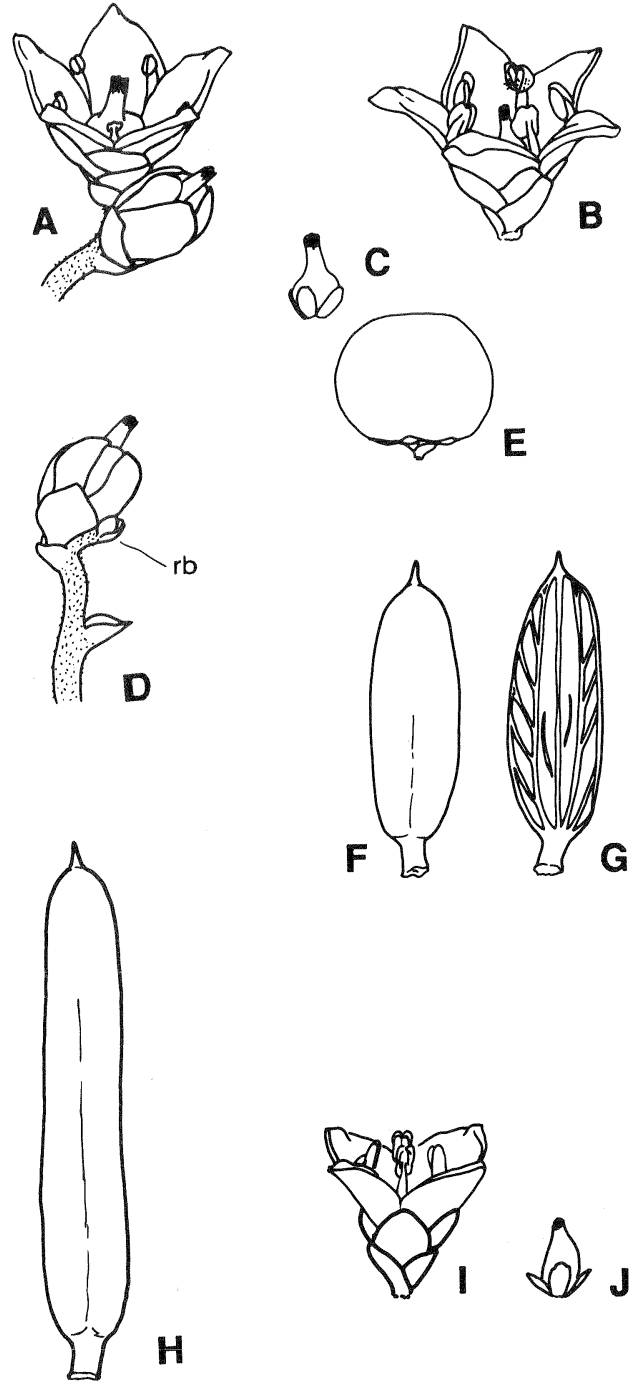

\section{E-H}

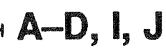

FIG. 3 - Monotoca linifolia ssp. algida: (A) flower (female), (B) flower (hermaphrodite), (C) gynoecium, $(D)$ rudimentary bud $(r b)$, (E) fruit, $(F)$ leaf (upper surface), $(G)$ leaf (lower surface). M. linifolia ssp. linifolia: (H) leaf (upper surface), (I) flower, (J) gynoecium. (Scale bars $=5 \mathrm{~mm}$.)

\section{ACKNOWLEDGEMENTS}

We wish to thank Dr J.M. Powell (National Herbarium of NSW), Dr G. Kantvilas and Dr A.E. Orchard (Tasmanian Herbarium), and Dr R.K. Crowden (University of Tasmania) for helpful discussions on certain aspects of the work and/or for comments on the draft manuscript; Dr Kantvilas for corrections to the Latin descriptions; and Mr J. Sulikowski (Forestry Commission) for technical assistance with the drawings. One of the authors (CMM) received support for part of this work from a University of Tasmania Postgraduate Research Award.

\section{REFERENCES}

Buchanan, A.M., McGeary-Brown, A. \& Orchard, A.E., 1989: A CENSUS OF THE VASCULAR PLANTS OF TASMANIA. Tasm. Herb. Occas. Publ. 2, Hobart, Tasmania.

Crowden, R.K., 1986: Two new species of the genus Epacris (Epacridaceae) from Tasmania. Pap. Proc. R. Soc. Tasm. 120: 17-19.

CURTIS, W.M., 1963: THE STUDENT'S FLORA OF TASMANIA, PART 2. Government Printer, Hobart.

DAvies, J.B., 1988: Pre-Logging Botanical Survey. Report No.7, Mt Cleveland. Unpubl. rep. Forestry Commission, Hobart.

GraY, A., 1971: A new species of mountain heath from Tasmania. Muelleria 2: 143.

JARMAN, S.J., 1974: A new species of Cyathodes (Epacridaceae) from Tasmania. Pap. Proc. R. Soc. Tasm. 107: 53-55.

JARMAN, S.J., 1975: Experimental taxonomy in the family Epacridaceae. Unpubl. PhD thesis, Univ. Tasm.

JARMAn, S.J., 1988: Epacris curtisiae, a new species from northwestern Tasmania. Pap. Proc. R. Soc. Tasm. 122: 115-117.

JARMAN, S.J. \& CROWDEN, R.K., 1977: AN IDENTIFICATION KEY TO THE EPACRIDACEAE IN TASMANIA. University of Tasmania.

JARMAN, S.J. \& CRowden, R.K., 1978: New species in the family Epacridaceae. Pap. Proc. R. Soc. Tasm. 112: $1-3$.

Menadue, Y. \& Crowden, R.K., 1983: Morphological and chemical variation in populations of Richea scoparia and R. angustifolia (Epacridaceae). Aust.J. Bot. 31: 73-84.

Minaich, C.M., 1989: Leaf epicuticular waxes in the taxonomy of the Epacridaceae. Unpubl. PhD thesis, Univ. Tasm.

WILlis, J.H., 1972: A HANDBOOK TO PLANTS IN VICTORIA. VOL.2. Melbourne University Press.

(accepted 10 August 1990)

\section{S.J. Jarman}

Forestry Commission, GPO Box 207B, Hobart, Tasmania, Australia 7001; formerly Tasmanian Department of Parks, Wildlife and Heritage

C.H. Mihaich

Department of Plant Science, University of Tasmania, GPO

Box 252C, Hobart, Tasmania, Australia 7001 